\title{
ОСОБИСТІ ФІНАНСИ ТА ФІНАНСИ ДОМОГОСПОДАРСТВ ЯК РЕЗЕРВ ЕКОНОМІЧНОГО ЗРОСТАННЯ РЕГІОНІВ
}

\author{
І Чечетова Н. Ф., доктор економічних наук, \\ 2 Чечетова-Терашвілі Т. М., доктор економічних наук, \\ ${ }^{1}$ Харківський національний університет міського господарства ім. О. М. Бекетова, \\ ${ }^{2}$ Харківський національний економічний університет ім. С. Кузнеия, \\ Україна, м. Харків
}

DOI: https://doi.org/10.31435/rsglobal_ijite/30062019/6532

\begin{abstract}
ARTICLE INFO
Received 29 April 2019

Accepted 23 June 2019

Published 30 June 2019

\section{KEYWORDS}

financial system, household, personal finances, investments, stocks, real estate.

ABSTRACT

The influence of macro- and microeconomic environment to the management of households finance is investigated, and the basic methods and instruments of the management of households finance in the modern terms of the domestic economy are described. The article deals with the identification of additional resources investment as factors for the growth regional product. It is concluded that the importance of the household sector as a source of increasing the volume of investment, the transformation of which investment resources of the economy will enhance the coordination of interests of the population and territory, the conclusion of regional economies on the path of sustainable economic growth.
\end{abstract}

Citation: Чечетова Н. Ф., Чечетова-Терашвілі Т. М. (2019) Osobysti Finansy ta Finansy Domohospodarstv yak Rezerv Ekonomichnoho Zrostannia Rehioniv. International Journal of Innovative Technologies in Economy. 4(24). doi: 10.31435/rsglobal_ijite/30062019/6532

Copyright: (C) 2019 Чечетова Н. Ф., Чечетова-Терашвілі Т. М. This is an open-access article distributed under the terms of the Creative Commons Attribution License (CC BY). The use, distribution or reproduction in other forums is permitted, provided the original author(s) or licensor are credited and that the original publication in this journal is cited, in accordance with accepted academic practice. No use, distribution or reproduction is permitted which does not comply with these terms.

Вступ. Останнім часом спостерігається зростання інтересу до економіки домогосподарства, яке розглядається як соціально-економічна осередок, що об'єднує людей відносинами, які виникають при організації ї спільної життєдіяльності. Зокрема, з'явилися наукові публікації, присвячені вивченню фінансів населення і їх ролі в фінансовій системі країни. Натомість, на сьогоднішній день існують дві точки зору 3 приводу можливості виділення фінансів домашнього господарства як самостійного об'єкта дослідження фінансової науки. Одні дослідники вважають, що фінанси домашніх господарств не можуть бути використані в якості самостійної категорії фінансової науки і не можуть бути віднесені до числа елементів фінансової системи, водночас інші науковці вважають використання даної категорії цілком прийнятним. На нашу думку, домашні господарства слід вважати рівноправним суб'єктом економіки, який регулює споживання створюваних в економіці благ та одночасно забезпечує національну економіку своїми ресурсами.

Результати дослідження. Дослідження фінансів домогосподарств має відбуватися на двох рівнях. На макрорівні здійснюється вивчення домогосподарств як певної сукупності економічних одиниць, поведінка яких безпосередньо відображає реальний фінансовий стан населення, його економічні інтереси, проблеми в цілому і має суттєвий вплив на національну економіку. На макроекономічному рівні можуть розглядатися в сукупності доходи домогосподарств, структура та обсяги споживання, фінансові взаємини щодо податків, пенсійного забезпечення, соціальної підтримки. Отримана інформація слугуватиме для прийняття державними інституціями рішень щодо планування доходів та видатків державного бюджету, розрахунку обсягу соціальних 
субвенцій, а також буде підгрунтям для формування стратегічних планів держави. Крім того, індикатори фінансового стану вітчизняних домогосподарств необхідно порівнювати 3 такими ж індикаторами в країнах 3 високим рівнем розвитку економіки та приймати рішення різного характеру: фінансові, інвестиційні, освітні, споживчі тощо.

Вивчення домогосподарств на мікрорівні включає дослідження фінансового стану домогосподарств щодо його впливу на економіку регіону або економіку відповідного міста, села тощо. Проте, якщо на макрорівні досліджуються узагальнюючі показники, то на рівні регіону місцева влада вже має отримувати більш детальну інформацію щодо фінансового стану конкретних домогосподарств, окремих груп населення та особистостей. На цьому рівні формується інформація щодо рівня доходів домогосподарств, яка необхідна для формування та розподілу соціальних субвенцій, а також соціальних видатків місцевих бюджетів.Процес децентралізації значно активізував зацікавленість як державної так i місцевої влади до фінансового стану домогосподарств. Адже об'єднанню громад передував аналіз фінансової спроможності кожної громади та ії складових - домогосподарств. Ця інформація дозволяє визначати стратегічні плани розвитку об’єднаних територіальних громад. Відповідно в суспільстві все більше дозріває розуміння необхідності глибокого і всебічного вивчення фінансів населення як перспективного джерела залучення ресурсів для розвитку економіки, а з точки зору формування доходів населення - як найважливішої складової відтворення людського капіталу. Водночас, дослідження фінансів домогосподарств має відбуватися одночасно з дослідженням особистих фінансів. Адже особисті фінанси відіграють важливу роль у розвитку економіки будь-якого регіону, оскільки охоплюють інтереси населення, регіональних органів влади та підприємств. Вплив особистих фінансів на розвиток економіки регіону полягає в тому, що з їх допомогою населення бере участь у розподілі і перерозподілі національного доходу. Звідси вважаємо, що особисті фінанси також слід виділяти в самостійну ланку фінансової системи.

У фінансовій системі особисті фінанси відіграють особливу роль і мають певні особливості, які відрізняють їх від державних, муніципальних та корпоративних фінансів. По-перше, особисті фінанси первинні по відношенню до державних, муніципальних та корпоративних фінансів, оскільки особа самостійно приймає рішення щодо напрямів застосування своїх доходів та грошових заощаджень, а також самостійно вибирає місце свого працевлаштування (застосування людського капіталу). По-друге, застосування особистого людського капіталу служать базою для формування місцевих та корпоративних фінансів адже їх праця формує додану вартість, яка певним чином трансформується в фінансовий капітал особи, підприємств та громади.

У вітчизняній фінансовій літературі вживаються поняття: «фінанси населення», «фінанси домашніх господарств», «фінанси домашніх господарств і соціальної сфери», «особисті фінанси», «персональні фінанси», «фінанси громадян», «фінанси фізичних осіб», «фінанси споживачів», «фінанси споживчого сектора». Проте офіційна економічна наука уникає поняття «особисті фінанси», в більшості оперуючи поняттям «домогосподарство», $\mathrm{i}$ тому єдиного та загальновизнаного визначення поняття особистих фінансів немає. Відсутнє це поняття і в законодавчій базі держави. Водночас, якщо підсумувати окремі наукові наробки та практичний досвід вивчення фінансів, то можна запропонувати таке визначення особистих фінансів, як загального доходу фізичної особи у вигляді заробітної плати та інших видів доходів, який витрачається, зберігається або інвестується з метою задоволення особистих потреб та досягнення визначених особою життєвих цілей. Основна мета особистих фінансів, це забезпечення процесу особистого споживання індивідуума незалежно від того, яке місце в суспільстві він займає. Важливо також враховувати, що основними одержувачами доходів все ж є особа, а не сім'я (домогосподарство), і рішення щодо видатків частіше приймаються окремими особами. Водночас, слід підкреслити, що особисті фінанси все ж $є$ підсистемою фінансів домогосподарства.

Слід окреслити певні властивості особистих фінансів: суб'єкт та об'єкт фінансової діяльності в основному тотожні, адже особа свої доходи витрачає в значному обсязі на себе; законодавством чітко визначена база та ставки оподаткування доходів; існування домогосподарства, яке забезпечує певні життєві потреби; безумовна приналежність особистих фінансів конкретній фізичній особі; повна свобода щодо сфери отримання доходів, здійснення видатків, заощаджень; ризики в прийнятті рішень щодо фінансових вкладень є особистими.

На сьогодні складно відстежувати позитивні та негативні сторони розвитку саме особистих фінансів, оскільки відсутні, та й, мабуть, неможливо унормувати та видати 
рекомендації щодо загальних вимог використання доходів особи, адже ці процеси в кожній родині (домогосподарстві) узгоджуються з безліччю індивідуальних особливостей. Наука не може виробити ні спеціальних законів, ні систем управління процесом формування доходів сім'ї, розмірами доходу, а тим більше рекомендацій по управлінню і структурі витрат. Якщо звернутися до статистичної інформації, то вона в більшості представляє інформацію щодо домогосподарств. А оскільки, як уже було зазначено вище, особисті фінанси є підсистемою фінансів домогосподарства, то відповідна динаміка стану фінансів домогосподарств корелюється зі станом особистих фінансів.

Слід зазначити, що фінансові ресурси домашнього господарства виступають у вигляді відособлених грошових фондів, що мають цільове призначення. При розподілі фінансових ресурсів в домогосподарстві на перше місце виходять сімейні цінності та особисті пріоритети. Внутрішньосімейний порядок визначає, яким чином будуть витрачатися кошти. Зокрема, можна зазначити, що в домогосподарствах створюються два основних фонди: фонд споживання, призначений для задоволення особистих потреб сім'ї (придбання продуктів харчування, товарів промислового виробництва, оплата різних послуг тощо); фонд заощаджень (відкладених потреб), який буде використаний в майбутньому для придбання дорогих товарів (побутова техніка, нерухомість тощо.) або як капітал для отримання прибутку.

Оцінюючи в цілому фінансові результати функціонування домогосподарств в Україні за досліджуваний період, слід відзначити зростання темпів росту доходів та витрат (табл. 1).

Таблиця 1. Динаміка доходів, витрат та заощаджень домогосподарств*

\begin{tabular}{|l|c|c|c|c|c|}
\hline Показники & 2014 & 2015 & 2016 & 2017 & 2018 \\
\hline Доходи, млн. грин. & 1516768 & 1735858 & 1989771 & 2475826 & 3219518 \\
\hline Витрати, млн. грн., в т. ч.: & 1485988 & 1722879 & 2007662 & 2544806 & 3219518 \\
\hline $\begin{array}{l}\text { на придбання товарів і } \\
\text { послуг, млн. грн. }\end{array}$ & 1316757 & 1553757 & 1815142 & 2297573 & 2870156 \\
\hline $\begin{array}{l}\text { Частка витрат на придбання } \\
\text { товарів і послуг, \% }\end{array}$ & 81,3 & 87,2 & 87,3 & 89,2 & 89,2 \\
\hline
\end{tabular}

Джерело: *розраховано за матеріалами джерела [3]

Протягом останніх років головним джерелом доходів населення країни традиційно $\epsilon$ оплата праці, яка становить близько $50 \%$ від обсягу всіх доходів. Значний внесок у формування доходів населення вносять соціальні допомоги та інші поточні трансферти, хоча частка таких доходів щорічно зменшується. Так, якщо у 2009 році вона становила 40,8\% від всіх доходів, то вже у 2018 році - 35,6\%. Частка доходів від власності також має тенденцію до зменшення, а саме: $3,9 \%$ у 2009 році та 1,6 \% у 2018 році. Проте у продовж досліджуваного періоду доходи від власності становили біля 6\%. Протилежною складовою фінансів домогосподарств $\epsilon$ витрати. У структурі витрат домогосподарств найбільшу частку займають витрати на придбання товарів та послуг - близько 90\% за 2018 рік. 3 них, найбільший відсоток становлять витрати на продукти харчування - маже $50 \%$ та комунальні послуги - біля $21 \%$. Водночас домогосподарства мають і заощадження, які можуть стати одним 3 джерел фінансування інвестиційних програм регіону (табл. 2).

Таблиця 2. Структура та динаміка заощаджень населення України, млн. грн.

\begin{tabular}{|l|c|c|c|c|c|}
\hline \multicolumn{1}{|c|}{ Показники } & 2014 & 2015 & 2016 & 2017 & 2018 \\
\hline 1. Приріст фінансових активів & 27868 & 15096 & -12410 & -12813 & 35805 \\
\hline $\begin{array}{l}\text { 2. Приріст грошових вкладів та } \\
\text { заощаджень у цінних паперах }\end{array}$ & 118734 & 10630 & 632528 & -579 & 66180 \\
\hline $\begin{array}{l}\text { 3. Заощадження в іноземній } \\
\text { валюті }\end{array}$ & 32472 & 22836 & 63243 & 63243 & 39787 \\
\hline $\begin{array}{l}\text { 4. Позики, одержані за } \\
\text { виключенням погашених }\end{array}$ & -40115 & -82752 & -20518 & 15486 & 29416 \\
\hline
\end{tabular}

*Джерело: розраховано за матеріалами джерела [3]

Заощадження домогосподарств мають величезне значення для самого домогосподарства, i одночасно представляють собою важливий потенціал економічного розвитку регіону. У країнах 3 
розвиненою ринковою економікою фінансові накопичення домогосподарств можна зіставити 3 обсягом ВВП, що, безумовно, є перспективою для економіки України. Наприклад, в США особисті фінанси складають 300\% частки від ВВП країни, в Японії - 245\%, а у Франції - 135\% [4].

Активізація інвестиційних процесів за рахунок залучення фінансових ресурсів домогосподарств можлива за умови вдосконалення фінансових інструментів і формування стимулів з боку державних та регіональних органів державної влади, які дозволять підвищити мотивацію населення в інвестуванні своїх грошових заощаджень в економіку регіонів.

Натомість, щоб грамотно та ефективно здійснювати інвестиційну діяльність, домогосподарствам необхідно знати про можливі інструменти інвестування вільних коштів, їх особливості, основні переваги та недоліки. В сучасних умовах досить важливим $\epsilon$ пошук надійних і найбільш вигідних інструментів інвестування. На даному етапі розвитку фінансових ринків існує безліч способів вкладення тимчасово вільних грошових коштів, тому важливо вміти розбиратися у всіх інструментах, необхідно мати відповідні знання про них і про ризики, які можуть бути пов'язані 3 вкладенням коштів в ті чи інші інструменти. Водночас, щоб не помилитися 3 вибором інструменту інвестування, потрібно враховувати не тільки свої побажання, але і фактори зовнішнього середовища, до яких можна віднести загальні економічні та політичні умови в країні, що впливають на ефективність використання кожного інструмента.

Так ще можна вкладати свої заощадження в акції. Проте потрібно грамотно підходити до вибору цінних паперів, вибирати більш надійні підприємства, які з найбільшою ймовірністю можуть благополучно пережити економічно нестабільну ситуацію в країні, або, можливо, й кризу. Більш надійними можуть бути облігації, адже вони мають фіксований рівень доходу до кінця терміну погашення, але щоб убезпечити себе від можливих втрат, потрібно провести аналіз діяльності організації та виявити перспективи іiі подальшого розвитку. Тому щоб бути успішним учасником фондового ринку, потрібно добре розбиратися в цій сфері, мати досить високий рівень фінансової грамотності.

Що стосується нерухомості як інструменту інвестування, то існує два способи заробляння: придбання з подальшим перепродажем та придбання нерухомості для подальшої здачі іï в оренду. При нинішній економічній ситуації в країні найкращим варіантом буде придбання нерухомості не для продажу, адже це дозволить отримувати постійний дохід, крім того за допомогою нерухомості можна зберегти свої кошти. Величезним мінусом тут є те, що на придбання нерухомості потрібні значні кошти. До того ж не кожне домогосподарство може собі це дозволити, а брати іпотеку під час економічної нестабільності є не найкращим варіантом, оскільки існує дуже високий ризик опинитися неплатоспроможним.

Вкладати кошти в золото з метою його подальшого перепродажу невигідно, але цей інструмент інвестування можна розглядати як хороший варіант збереження своїх коштів при несприятливих економічних умовах. Також слід зазначити, що ставки депозитів в економічно нестабільній економіці не перевищують темпу зростання інфляції, тому розглядати депозит як інструмент примноження вільних коштів в таких економічних умовах не варто, але депозит можна використовувати як інструмент збереження своїх коштів. Можна відзначити, що в нестабільній економіці найпривабливішою стає покупка валюти, адже в такі часи завжди спостерігається зростання курсу іноземної валюти.

На підставі вищезазначеного можна відзначити, що найбільшу частку своїх витрат домогосподарства витрачають на поточне споживання, а на заощадження і подальше їх інвестування залишається незначна частина коштів, що обмежує інвестиційну діяльність громадян. Натомість, для економічного зростання регіону велике значення має інвестиційна функція грошових потоків домашніх господарств як постачальників фінансових ресурсів для економіки. В даний час не тільки низький рівень доходів основної маси домогосподарств $є$ стримуючим фактором інвестиційного процесу, а й недостатня фінансова грамотність більшої частини населення.

Ще однією прогалиною в фінансовій системі $є$ відсутність фінансових фахівцівконсультантів для населення, які могли б індивідуально порекомендувати відповідний ефективний напрямок інвестування, виходячи 3 суми заощаджень домогосподарства або особистих фінансів громадянина. Разом 3 тим фінансово-кредитні інститути покликані відігравати провідну роль в процесі вибору населенням інструментів інвестування заощаджень, впливати на трансформацію заощаджень в інвестиції та на підвищення реальної норми доходів і заощаджень домашніх господарств. 
Висновки. Виходячи 3 вищезазначеного зауважимо, що питання інвестиційної активності громадян та домогосподарств обумовлюють актуальність розробки нових методів і моделей оцінки та прогнозування грошових потоків домогосподарств та стимулювання їх зростання, які несуть великий інвестиційний потенціал та здатні зміцнити ресурсну базу регіональних бюджетів.

\section{ЛIТЕРАТУРА}

1. Ватаманюк О. Заощадження в економіці України: макроекономічний аналіз : монографія. Львів : ЛНУ ім. І. Франка, 2007. 536 с.

2. Гладких Д. М. Стабілізація банківської системи шляхом підвищення довіри до банків та забезпечення прозорості діяльності НБУ. Аналітична доповідь // [Електронний ресурс]. - Режим доступу: http://www.niss.gov.ua

3. Державна служба статистики України [Електронний ресурс]. - Режим доступу: http://www.ukrstat.gov.ua

4. Екшембиев Р. С. Персональные финансы в финансовой системе государства. М.: Магистр, 2011. 302 с.

5. Кізима Т. О. Фінанси домогосподарств: сучасна парадигма та домінанти розвитку : моногр. / Т. О. Кізима. - К. : Знання, 2010. -431 с.

6. Сидорова А., Коваленко А. Доходи та витрати населення: статистичне оцінювання, моделювання та прогнозування. Фінанси, облік, банки. 2017. № 1 (22). С. 154-162.

7. Фінансовий потенціал регіону: механізми формування та використання : монографія / НАН України. Інститут регіональних досліджень ; за наук. ред. М.А. Козоріз. - Львів, 2012. - С. 253. - 307 с.

8. Финогенова Ю.Ю. Страховой риск-менеджмент персонального инвестора: монография. М.: Мирбис, 2011.246 с.

9. Финансы домашнего хозяйства: инвестиционный аспект. - СПб.: Изд-во С.Петерб. ун-та, 2006. 194 c. 10

10. Франченко О.Л. Використання заощаджень населення в інвестування економіки країни через структури фондового ринку / О.Л. Франченко // Економічний часопис XXI. - 2010. - № 9-10. - С. 26-29.

11. Personal financial markets, ed. by R. Carter, B. Chiplin and M. Lewis, Coventry: Philip Allan Publishers Ltd., 1986. 